\title{
DOES THE UN SECURITY COUNCIL COMPOUND THE GLOBAL DEMOCRATIC DEFICIT?
}

\author{
JEREMY FARRALL ${ }^{*}$
}

Since the end of the Cold War, the UN Security Council has frequently endorsed the notion that democracy and democratic governance are desirable preconditions for domestic stability and international peace and security. However, the Security Council's response to the 2008 Zimbabwean presidential elections called into question, perhaps for the first time since the end of the Cold War, its commitment to democracy as the preferred from of domestic governance. In this article, the author discusses the concept of the democratic deficit and explores its application to the UN Security Council. In addition, the author examines the relationship between democracy and international law, retracing the argument that there is an international norm promoting democratic governance. Finally, the author examines the relationship between the Security Council and democracy, suggesting a growing formal commitment to democracy, particularly in post-conflict environments.
Depuis la fin de la guerre froide, le Conseil de sécurité de l'ONU a souvent approuvé la notion que la démocratie et la gouvernance démocratique sont des conditions souhaitables à la stabilité intérieure et la paix et sécurité internationale. Cependant, la réaction du Conseil de sécurité aux élections présidentielles au Zimbabwe en 2008 contesta, peut-être pour la première fois depuis la fin de la guerre froide, son engagement envers la démocratie comme forme privilégiée de gouvernance intérieure. Dans l'article, l'auteur discute du concept de déficit démocratique et en examine l'application au Conseil de sécurité. En outre, l'auteur examine la relation entre démocratie et droit international, reconstituant l'allégation d'une norme internationale promouvant la démocratie. Enfin, l'auteur examine la relation entre le Conseil de sécurité et la démocratie en laissant entendre un engagement officiel de plus en plus grand pour la démocratie, surtout après des conflits.

\section{TABLE OF CONTENTS}

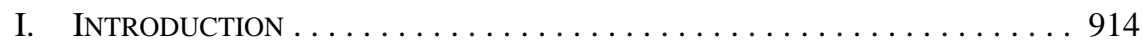

II. What IS “DEMOCRATIC DEFICIT" AND What DoEs IT

IMPLY IN THE CONTEXT OF THE UN SECURITY COUNCIL? . . . . . . . . 917

III. The UN SECURITY COUNCIL AND InTERnATIONAL LAW . . . . . . . . . 919

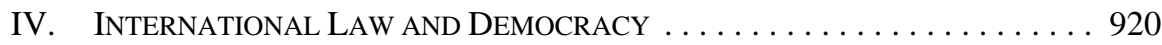

V. UN SECURity Council DeCisions Promoting DeMOCRACY . . . . . . . 922

A. Chapter ViI Decisions Promoting Democracy ......... 922

B. OtHer SECURITY COUNCIL DECISIONS

Promoting Democracy . . . . . . . . . . . . . . . . . . . 926

VI. RE-EVAluATING THE COUNCIL'S

RELATIONSHIP WITH DEMOCRACY . . . . . . . . . . . . . . . 929

A. Re-evaluating the Democratic Norm Thesis $\ldots \ldots \ldots . . .929$

B. Re-EVAluating the COUNCIL'S RELATIONSHIP

WITH THE DEMOCRATIC DEFICIT $\ldots \ldots \ldots \ldots \ldots \ldots \ldots$

VII. LOOKING TO the FUtURE $\ldots \ldots \ldots \ldots \ldots \ldots \ldots \ldots \ldots \ldots \ldots$

B.A. (Hons.), LL.B. (Hons.) Melbourne, Ph.D. Tasmania, Research Fellow, Centre for International Governance and Justice, the Australian National University. 


\section{INTRODUCTION}

Are we witnessing the demise of democracy as a global norm? On 11 July 2008, on a hot and humid afternoon in New York city, China and Russia vetoed a United Nations Security Council draft resolution on Zimbabwe. The resolution would have applied targeted sanctions against Zimbabwean President Robert Mugabe and key members of his regime, with the primary objective of restoring democracy to a broken nation. ${ }^{1}$

In the first half of 2008, Mugabe ran an orchestrated campaign to obstruct the Zimbabwean opposition's legitimate efforts to win government at the ballot box. Members and supporters of the opposition party Movement for Democratic Change (MDC) were harassed, intimidated, and in some instances subjected to murderous physical violence. Against all odds, in the parliamentary elections held on 29 March 2008, the MDC managed to win a greater number of seats than Mugabe's ruling party, giving it a parliamentary majority for the first time. But the results of the presidential elections, which were held the very same day, were never fully released. The Zimbabwe Electoral Commission, itself apparently subjected to governmental intimidation, delayed the release of the presidential results for more than a month, eventually announcing unconvincingly that there was a need for a runoff election between Mugabe and the leader of the MDC, Morgan Tsvangirai. Tsvangirai, who had been forced into exile following the first-round election, thought long and hard before deciding to contest the runoff. But soon after his return to Zimbabwe, as MDC party members and their supporters fell victim to increasingly violent attacks by bands of militia loyal to Mugabe, Tsvangirai was forced to withdraw his candidature. This opened the way for Mugabe to be re-“elected” unopposed. International criticism of the Zimbabwean "elections" was united and deafening. A multitude of critics denounced the electoral process as anything but free and fair.

Since the end of the Cold War, the UN Security Council has frequently endorsed the notion that democracy and democratic governance are desirable preconditions for domestic stability and international peace and security. The Council's own actions in support of democracy in the 1990s, particularly in cases such as Haiti and Sierra Leone, demonstrated that the Council was prepared not only to engage in rhetoric on the importance of democracy, but also to take robust action to protect democratic governance. ${ }^{2}$ In each of those situations, the Council identified the ouster of a democratically elected government as a threat to international peace and security warranting Chapter $\mathrm{VII}^{3}$ action, in the form of sanctions, against those who threatened democracy. This record of Chapter VII action to protect democracy, combined with the Council's frequent support for free and fair elections in many

Australia, Belgium, Canada, Croatia, France, Italy, Liberia, Netherlands, New Zealand, Sierra Leone, United Kingdom of Great Britain and Northern Ireland and the United States of America: draft resolution, UN SCOR, 2008, UN Doc. S/2008/447 [Zimbabwe Draft Resolution]. The result of the vote was nine for, five against (China, Libya, Russia, South Africa, and Vietnam) and one abstention (Indonesia): see UN SCOR, 63d Year, 5933d Mtg., UN Doc. S/PV.5933 (2008) at 7-8 [provisional] [UN Doc. S/PV.5933]. In accordance with the voting procedure in the Security Council, nine votes in favour is sufficient for a draft to be adopted, provided that there is no negative vote by a permanent member: Charter of the United Nations, 26 June 1945, Can. T.S. 1945 No. 7, art. 27(3) [UN Charter]. 
theatres where it has established peacekeeping operations, including Namibia, Cambodia, Bosnia, Liberia, Timor Leste, Haiti, and the Democratic Republic of the Congo (DRC), to name but a few, have reinforced the claims of international lawyers that there is a right to democratic governance ${ }^{4}$ and a companion "democratic norm" at the international level requiring the promotion of democracy and democratic governance.

However, the Security Council's response to events in Zimbabwe called into question, perhaps for the first time since the end of the Cold War, its commitment to democracy as the preferred form of domestic governance. If adopted, the Council's draft resolution on Zimbabwe would have expressed strong concern at "irregularities during the 27 June Presidential election, the violence and intimidation perpetrated in the run up to the election that made impossible the holding of free and fair elections." 5 The vetoed resolution would also have expressed strong concern over "the grave humanitarian situation in Zimbabwe.” It would have then characterized the situation in Zimbabwe as a "a threat to international peace and security in the region"7 and imposed a range of targeted sanctions, including an arms embargo against Zimbabwe, as well as a travel ban and an assets freeze against Mugabe and key members of his regime. ${ }^{8}$

Security Council debate surrounding the draft resolution recalled the polarized atmosphere of the Cold War era. The nations that voted against the draft resolution alleged that it would have amounted to an illegitimate interference in the domestic affairs of a UN member state. Libya contended that the dispute was "between Zimbabwean parties," that the situation was "in no way a threat to regional peace and security," and that it therefore did not fall within the purview of the Security Council's mandate. ${ }^{9}$ It argued that the draft resolution constituted “a violation of Zimbabwe's sovereignty and interference in its internal affairs." ${ }^{10}$ Russia alleged that the draft resolution amounted to an "attempt to take the Council beyond its Charter prerogatives and beyond the maintenance of international peace and security." ${ }^{11}$ It felt that Zimbabwe's problems could not be resolved "by artificially elevating them to the level of a threat to international peace and security"12 and that the proposed action was "illegitimate and dangerous and apt to lead to a realignment of the entire United Nations system."13 Ominously, Russia even went so far as to declare its intention "to continue to counter such trends, so that all States without exception will firmly comply with the [UN] Charter." ${ }^{14}$ China expressed the view that "the development of the situation in Zimbabwe to

See Thomas M. Franck, “The Emerging Right to Democratic Governance” (1992) 86 A.J.I.L. 46; Gregory H. Fox, “The Right to Political Participation in International Law” (1992) 17 Yale J. Int'l L. 539; Gregory H. Fox \& Brad R. Roth, eds., Democratic Governance and International Law (Cambridge, N.Y.: Cambridge University Press, 2000); Susan Marks, The Riddle of all Constitutions: International Law, Democracy, and the Critique of Ideology (Oxford: Oxford University Press, 2000). For further discussion of the right to democratic governance see Part IV, below.

Zimbabwe Draft Resolution, supra note 1, Preamble.

Ibid.

Ibid.

Ibid. at paras. 4-7.

UN Doc. S/PV.5933, supra note 1 at 5.

Ibid.

Ibid. at 9.

Ibid.

Ibid.

Ibid. 
date has not gone beyond the realm of internal affairs. It does not constitute a threat to the world's peace and security.”15

These positions were vigorously contested by the countries that voted in favour of the draft. The United Kingdom described the situation as "a moment of truth for democracy in Africa" and bemoaned the fact that the Security Council had "failed to shoulder its responsibility to do what it can to prevent a national tragedy deepening and spreading its effects across Southern Africa." ${ }^{16}$ It characterized the stance of those who had voted against the draft as "inexplicable” and "deeply damaging to the long-term interests of Zimbabwe's people." ${ }^{17}$ France described what had happened in Zimbabwe as "a parody of an election and a denial of democracy." ${ }^{18}$ Costa Rica emphasized that "free and fair elections are essential to protecting and promoting human rights and the rule of law." ${ }^{19}$ In a strong, tersely-worded statement, the United States alleged that "China and Russia have stood with Mugabe against the people of Zimbabwe." ${ }^{20}$ It further described the situation in Zimbabwe as the "single greatest challenge to regional stability in Southern Africa."21

Ultimately the situation in Zimbabwe was resolved, albeit temporarily and imperfectly, not by the UN Security Council but through the intervention of the South African Development Community (SADC), which brokered a power-sharing agreement between Mugabe and Tsvangirai. ${ }^{22}$ The UN's detractors will point to the Security Council's failure to adopt the draft resolution on Zimbabwe as evidence of its undemocratic, even antidemocratic, nature. ${ }^{23}$ This article argues, however, that the case that the Security Council compounds the global democratic deficit is not so clear-cut. It explores the relationship between the UN Security Council and democratic governance in the post-Cold War era and argues that the Security Council's relationship with democracy is better entrenched and more complex than the UN's critics would have us believe. In fact, the Council has played an increasingly constructive and diverse role in support of democracy and democratic governance, particularly in post-conflict environments. So, although the Zimbabwe case serves as a healthy reminder that little can be taken for granted when it comes to the UN Security Council, the rumours of democracy's demise are somewhat exaggerated.

Part II of this article introduces the concept of democratic deficit and explores its application to the UN Security Council. Part III describes the relationship between the Security Council and international law. Part IV explores the relationship between democracy and international law, retracing the argument that there is an international norm promoting

Ibid. at 13 .

Ibid. at 8.

Ibid. at 9 .

Ibid. at 10 .

Ibid. at 11.

Ibid. at 14.

Ibid.

For an overview of the process leading to the 15 September 2008 signing of the Global Political Agreement between Mugabe's ZANU-PF party and Tsvangirai's MDC, as well as an assessment of the agreement's implementation over the following eight months, see International Crisis Group, Policy Briefing, Africa Briefing No. 59, “Zimbabwe: Engaging the Inclusive Government” (20 April 2009) at 2-4.

23 For a strident example of such a UN detractor, see John Bolton, Surrender Is Not An Option: Defending America at the United Nations and Abroad (New York: Threshold Editions, 2007). 
democratic governance. Part V examines the relationship between the Security Council and democracy, illustrating the Council's growing formal commitment to democracy, particularly in post-conflict environments. Part VI then draws upon analysis in the previous Parts to reevaluate both the current status of the democratic norm and the Security Council's relationship with democratic deficit.

\section{WHAT IS “DEMOCRATIC DEFICIT” AND WHAT DOES IT IMPLY IN THE CONTEXT OF THE UN SECURITY COUNCIL?}

The term "democratic deficit" is a euphemism employed to denote that a society or institution is undemocratic. It can be used at the domestic level to critique a given democratic system, but it is also frequently used at the global level to paint the global normative decision-making process and global institutions as undemocratic. Andrew Moravscik has speculated that the issue of whether global governance suffers from a democratic deficit is "one of the central questions - perhaps the central question — in contemporary world politics." 24 Among the global institutions that often find themselves the target of democratic deficit critique are the World Trade Organization, the World Bank, and the primary organs of the UN, including the General Assembly and the Security Council.

Before exploring the application of democratic deficit analysis to the UN Security Council, it is useful to recall that even in domestic settings the employment of such a tool is controversial. First, as many scholars point out, while the ideal of democracy can be approached, its definition is vigorously contested ${ }^{25}$ and it is impossible to realize fully. ${ }^{26}$ Thus, the assumption underpinning the use of the term "democratic deficit," namely that it is possible to reach "democratic surfeit," or even "democratic equilibrium," is itself open to question. Second, it does not necessarily follow that just because an institution is undemocratic that it cannot engage in activities that promote democracy.

The Security Council could be criticized on multiple levels for being in democratic deficit. First, the fact that the UN Charter gives permanent Security Council membership and the power to veto any decision of substance to five states (the P5), is inherently undemocratic. The veto power places China, France, Russia, the U.K., and the U.S. on a different playing field from the other $187 \mathrm{UN}$ member states, ${ }^{27}$ making the P5 more equal than the others. Second, many nations that sit on the General Assembly and the Security Council do not themselves qualify as democracies. Third, the Security Council could be criticized for being

24 Andrew Moravcsik, "Is there a 'Democratic Deficit' in World Politics? A Framework for Analysis" (2004) 39 Government and Opposition 336 at 336 [emphasis in original].

$25 \quad$ Marks, supra note 4 at 2; Brett Bowden \& Hilary Charlesworth, "Defining Democracy in International Institutions” in Brett Bowden, Hilary Charlesworth \& Jeremy Farrall, eds., The Role of International Law in Rebuilding Societies after Conflict: Great Expectations (Cambridge: Cambridge University Press, 2009) 90.

26 See Robert A. Dahl, Polyarchy: Participation and Opposition (New Haven: Yale University Press, 1971). See also Maley's discussion of the matter: William Maley, "Democracy and Legitimation: Challenges in the Reconstitution of Political Processes in Afghanistan” in Bowden, Charlesworth \& Farrall, ibid., 111.

27 The admission of Montenegro as a UN member state on 28 June 2006 brought the total number of UN member states to 192: see General Assembly Approves Admission of Montenegro to United Nations, Increasing Number of Member States to 192, UN GAOR, 60th Sess., UN Doc. GA/10479 (2006), online: UN Press Releases \& Meetings Coverage <http://www.un.org/News/Press/docs/2006/ ga10479.htm>. 
insufficiently representative of the broader membership of the UN. The remaining ten seats on the Council are elected for two-year terms, with five incoming and five outgoing each year. This means that stints on the Security Council, the UN's most important decisionmaking body, are few and far between. For these reasons, concerted efforts have been undertaken for more than a decade to bring about an expansion to the Security Council. ${ }^{28}$

The basic implications of this style of democratic deficit analysis are twofold. First, it is unlikely that the Security Council, as an undemocratic body, would operate democratically and reach democratic outcomes in its decision-making. Second, it is equally unlikely that such an undemocratic entity would make decisions that serve the interests of democracy. The Security Council's failure to adopt the draft resolution on Zimbabwe would come as little surprise to those who argue that the Council is in democratic deficit. Why should it be expected to intervene to protect democracy in Zimbabwe when it is itself so undemocratic?

Yet despite its seemingly undemocratic nature, the UN Security Council has increasingly engaged in activities that seek to promote democracy. ${ }^{29}$ Perhaps the most visible and forceful UN actions in support of democracy have been the examples where the Security Council has characterized situations in which democracy is threatened as threats to the peace warranting the application of sanctions under Chapter VII of the UN Charter. ${ }^{30}$ If that were the only front on which the Council were to be judged in terms of reducing or compounding its democratic deficit, then it might be possible to argue that the Zimbabwe vote represented a substantial retreat in the Council's commitment to democracy. ${ }^{31}$ But the democracy promotion activities of both the UN and the Security Council extend beyond these limited examples of the use of Chapter VII powers to protect democracy. Within the UN Secretariat, the Department of Political Affairs has a unit, the Electoral Affairs Division, dedicated to providing electoral assistance to those states who request it. ${ }^{32}$ The Division received 363 official requests for electoral assistance between 1989 and 2005, delivering support to 96 countries. ${ }^{33}$ The UN's Department of Peacekeeping Operations supports the organization of elections in theatres where the UN Security Council has deployed peacekeeping operations. ${ }^{34}$

For the most authoritative proposals on such Security Council reform, see United Nations SecretaryGeneral's High-Level Panel on Threats, Challenges and Change, A More Secure World: Our Shared Responsibility (New York: United Nations, 2004) at paras. 250-56.

For a helpful overview of the various democracy promotion activities undertaken, supported, or facilitated by the UN, see Edward Newman, "UN Democracy Promotion: Comparative Advantages and Constraints” in Edward Newman \& Roland Rich, eds., The UN Role in Promoting Democracy: Between Ideals and Reality (Tokyo: United Nations University Press, 2004) 188. For further discussion, see Part V.A, below.

31 Even this proposition is open to debate, however, for there are considerable differences between the current situation in Zimbabwe and the factual circumstances that drew a Chapter VII response from the Security Council in the cases of Haiti and Sierra Leone. For further discussion, see also Part V.A, below. See Robin Ludwig, "The UN's Electoral Assistance: Challenges, Accomplishments, Prospects" in Newman \& Rich, supra note 29, 169.

33 See online: UN Electoral Assistance Division <http://www.un.org/Depts/dpa/ead/overview.html\# Statistics>.

34 For a social science-based analysis of the promotion of democratization through UN peacekeeping, see Virginia Page Fortna, "Peacekeeping and Democratization” in Anna K. Jarstad \& Timothy D. Sisk, eds., From War to Democracy: Dilemmas of Peacebuilding (Cambridge: Cambridge University Press, 2008) 39. 
A UN agency, the UN Development Programme (UNDP), also plays a major role in support of democratization and democratic governance. ${ }^{35}$

The answer to the question of whether the UN Security Council reduces or compounds the democratic deficit is thus not as clear-cut as the UN's critics would have us believe. One objective of this article is to illustrate that the Council's relationship with democracy is more nuanced, and its commitment to the promotion of democracy stronger, than is commonly assumed either by the Council's extreme critics or by those who pin the Council's democratic credentials to its Chapter VII decisions alone. The following three Parts thus turn to the nature and depth of the relationship between the Security Council and International Law, International Law and Democracy, and the Security Council and Democracy.

\section{THE UN SECURITY COUNCIL AND INTERNATIONAL LAW}

The relationship between the Security Council and international law is itself complex. On the one hand, the Council is a political body that makes decisions in an environment that is highly charged. On the other, by virtue of its power to issue decisions that are legally binding upon UN member states ${ }^{36}$ and to authorize mandatory non-military and military coercive action to maintain or restore international peace and security, ${ }^{37}$ the Council is a body whose activities have profound legal implications.

The Security Council's ability to create legal obligations that are binding on practically all states has led commentators to describe aspects of the Council's activities as quasilegislative in character. ${ }^{38}$ Although the Council's law-making process may be less sophisticated than the legislative mechanisms in many national parliamentary or congressional legislatures, the legal consequences flowing from Council decisions can bestow upon them a quality akin to legislation. Examples include the Council's resolutions requiring states to take global action to counter terrorism, beginning with Resolution 1373 (2001), as well as its decisions pressing for action to prevent the supply to non-state actors of weapons of mass destruction, commencing with Resolution 1540 (2004)..$^{39}$ On occasion, the Security Council has also declared certain activities to be illegal, thus interpreting and applying international law in a quasi-judicial manner. ${ }^{40}$

35 See Richard Ponzio, “UNDP Experience in Long-Term Democracy Assistance” in Newman \& Rich, supra note 29, 208.

UN Charter, supra note 1, arts. 25, 48.

Ibid., arts. 39, 41, 42.

Paul C. Szasz, “The Security Council Starts Legislating,” Note, (2002) 96 A.J.I.L. 901; José E. Alvarez, International Organizations as Law-makers (Oxford: Oxford University Press, 2005) at 184-98.

39 SC Res. 1373, UN SCOR, 2001, UN Doc. S/RES/1373; SC Res. 1540, UN SCOR, 2004, UN Doc. S/RES/1540.

40 Examples of the Council's law-interpreting activities include declarations regarding the illegality of claims of statehood in the cases of Southern Rhodesia, (SC Res. 216, UN SCOR, 1965, UN Doc. S/RES/216; SC Res. 217, UN SCOR, 1965, UN Doc. S/RES/217 at para. 3), and the "Turkish Republic of Northern Cyprus,” (SC Res. 541, UN SCOR, 1983, UN Doc. S/RES/541 at paras. 1-2; SC Res. 550, UN SCOR, 1984, UN Doc. S/RES/550 at para. 2), as well as declarations concerning boundary delimitation, as in the case of the border between Iraq and Kuwait, (SC Res. 687, UN SCOR, 1991, UN Doc. S/RES/687, Preamble, paras. 2-4). 
The Security Council's close relationship with law is particularly evident when it applies UN sanctions. ${ }^{41}$ Whenever the Council applies sanctions it enters quasi-legislative mode. The mandatory provisions of its sanctions resolutions establish the contours of each sanctions regime, creating a new web of legal obligations that amounts to legislation. ${ }^{42}$ The Council has also entered quasi-judicial mode in connection with its sanctions regimes. Indeed, prior to establishing its very first sanctions regime, the Council characterized the white minority regime in Southern Rhodesia as "illegal"43 and described its purported declaration of independence as having "no legal validity." ${ }^{44}$ The Council has made other quasi-judicial proclamations in connection with its sanctions regimes against Iraq and Haiti. In 1990, it declared Iraq's attempted annexation of Kuwait to have "no legal validity" 45 and stated that Iraq was liable under international law "for any loss, damage or injury arising in regard to Kuwait and third States" as a result of its "invasion and illegal occupation of Kuwait."46 In 1994, the Council described as "illegal" the de facto government that assumed control of Haiti following the ouster of the democratically-elected government of President JeanBertrand Aristide. $^{47}$

The Security Council's relationship with international law has important implications for the Council's interactions with democracy. As a body whose decisions are legally binding on UN member states, the Council has the ability to create new norms, as well as to reinforce or undermine existing norms. The Council's actions vis-à-vis democracy thus have a distinct influence on both the extent to which it is possible to say that there is a democratic norm, as well as upon the ability of the international community to take action to enforce such a norm.

\section{INTERNATIONAL LAW AND DEMOCRACY}

In 1992, a chorus of international lawyers began singing from the same song sheet. The Cold War had recently ended and there was a sense of optimism and expectation that democratization would sweep the globe, rendering communist totalitarian states and military dictatorships a thing of the past. ${ }^{48}$ This chorus sought to demonstrate that the spread of democracy was accompanied by equally momentous developments on the normative front. It did not really matter whether the new normative arrival was called the "right to democratic (Cambridge: Cambridge University Press, 2007).

For the legal web of obligations created in relation to each UN sanctions regime applied up until the end of 2006, see ibid., especially appendix 2.

SC Res. 216, supra note 40 at paras. 1-2; SC Res. 217, supra note 40 at para. 1.

SC Res. 217, ibid. at para. 3.

SC Res. 662, UN SCOR, 1990, UN Doc. S/RES/662 at para. 1.

SC Res. 674, UN SCOR, 1990, UN Doc. S/RES/674 at para. 8.

SC Res. 917, UN SCOR, 1994, UN Doc. S/RES/917 at para. 3(b).

For a helpful survey of the democratization movement, see Amichai Magen \& Leonardo Morlino, eds., International Actors, Democratization and the Rule of Law (New York: Routledge, 2009). 
governance," ${ }^{49}$ the "right to political participation," 50 or the "democracy norm." ${ }^{\text {"51 }}$ What seemed clear to most was that a new norm had emerged. ${ }^{52}$

Broadly speaking, the construction of the norm, which Susan Marks has termed the "democratic norm thesis," 53 drew upon a combination of long-recognized human rights, the fact that the number of democracies around the world was increasing rapidly, and a growth in both statements by and practice of international organizations reinforcing the importance of democracy. Among the rights drawn upon to create the "pedigree" of the right to democratic governance were those to self-determination, free political expression, and political participation. ${ }^{54}$ From the figures highlighted to illustrate the spread of democracies, the following narrative emerges: in 1960 there were 29 democracies; ${ }^{55}$ by 1990 this number had risen to $65 ;{ }^{56}$ and by late 1991 the number was $110 .{ }^{57}$ In terms of statements and practice of international organizations, international lawyers pointed to examples from regional organizations, such as the Organization of American States and the European Union, as well as various components of the UN system, including election monitoring supported by the UN General Assembly, Secretariat, and Security Council. ${ }^{58}$

Yet the proclamation of a new norm did not meet with unanimous adulation. Thomas Carothers, a long-time advocate of democracy promotion, expressed reservations. First, he identified a tendency to assert simplistically that democracy was spreading everywhere, without demonstrating empirically that this was occurring as a matter of fact. ${ }^{59}$ Second, Carothers objected to the equation of mere elections with democracy, observing that elections were "a necessary but not sufficient condition" for democracy. ${ }^{60}$ This point had not escaped Thomas Franck, who had conceded that the norm he was promoting was "not ambitious, ... not necessarily unambiguous, and ... almost certainly not the one an American would prefer." ${ }^{61}$ Nevertheless Franck felt that in the early 1990s his modest norm probably represented "the limit of what the still frail global system of states [could] be expected to accept."62

Since 1992, democracy's fate has waxed then waned. At first, the advance of democratic governance appeared to be inevitable. As noted above and discussed further in the following

See Franck, supra note 4.

See Fox, supra note 4.

See Marks, supra note 4 at 37-49.

For a dissonant voice, see Thomas Carothers, "Empirical Perspectives on the Emerging Norm of Democracy in International Law” (1992) 86 American Society of International Law Proceedings 261 (advancing a view that was critical of premature claims for such a norm).

Marks, supra note 4 at 37-45.

See Franck, supra note 4 at 52-64; Fox, supra note 4 at 552-70.

Fox, ibid. at 540.

Ibid.

Franck, supra note 4 at 47.

Fox, supra note 4 at 570-73.

Carothers, supra note 52 at 262.

Ibid. at 264.

Thomas M. Franck, "Democracy as a Human Right” in Louis Henkin \& John Lawrence Hargrove, eds., Human Rights: An Agenda for the Next Century, Studies in Transnational Legal Policy No. 26 (Washington, D.C.: American Society of International Law, 1994) 73 at 75. 
section, the UN Security Council even went so far as to use its Chapter VII powers to restore democracy in Haiti and Sierra Leone. But the Security Council's recent failure to act in the Zimbabwe instance could be portrayed as a serious backpedalling from those adventurous interventions. Indeed, even before events in Zimbabwe began to take shape, Carothers was concerned that democracy's lustre may have begun to fade. Writing in 2007, Carothers warned that the spread of democracy around the world, the essential first plank in the platform underpinning Franck's norm, was in dangerous retreat: “the 'third wave' of democracy is over... The momentum for global democratization has greatly faded or been lost in many parts of the world." ${ }^{\prime 3}$ Carothers then predicted gloomily that we were heading towards a new "heyday of the stronghand model of political and economic development, or what some call ‘authoritarian capitalism,' practiced primarily by China and Russia.”64

So where does this leave the democratic norm? Has it emerged, crystallized, or dissipated? While the skepticism of Carothers has only increased, loyal advocates of the norm maintain that its status is secure. Gregory Fox recently wrote that "it is now clear that international law and international organizations are no longer indifferent to the internal character of regimes exercising effective control within sovereign states." ${ }^{\text {"65 }}$ In his view, "[i]nternational law now undoubtedly addresses the democratic origins of political authority.”66

\section{UN SECURIty Council Decisions Promoting Democracy}

As Part III explained, the UN Security Council has an interesting relationship with international law. On the one hand, the Council is a political body with a political decisionmaking process that enables it to make decisions and take actions (or, indeed, to fail to take actions) that fly in the face of settled international law. ${ }^{67}$ On the other hand, however, the Council retains the ability to make new law at the international level. Its decisions and practice therefore carry particular influence and significance when it comes to assessing claims about the existence or endurance of international norms. Two broad categories of Security Council practice can be drawn upon to reinforce or contest claims regarding the democratic norm. First, there are high-profile examples where the Council has exercised its Chapter VII powers to restore democracy. Second, there is the general practice of the Council relating to democracy and democracy promotion, as evidenced by the text of all of its resolutions, whether or not adopted under Chapter VII.

\section{A. Chapter VII Decisions Promoting Democracy}

Chapter VII of the UN Charter empowers the UN Security Council to determine the existence of any threat to the peace, breach of the peace, or act of aggression, and to take

63 Thomas Carothers, “A Quarter-Century of Promoting Democracy” (2007) 18:4 Journal of Democracy 112 at 113.

Ibid. at 115 .

Gregory H. Fox, “Internationalizing National Politics: Lessons for International Organizations” (2007) 13 Widener Law Review 265 at 267.

Ibid. at 269.

Thus, for example in the case of Georgia, the Council's hands are currently tied, preventing it from responding effectively to Russia's intervention, which appears to be a clear violation of the prohibitions on the use of force and interference in the domestic jurisdiction of UN member states under arts. 2(4) and 2(7) of the UN Charter, supra note 1. 
coercive action, including the application of non-military sanctions and the employment of military force, in order to maintain or restore international peace and security ${ }^{68}$ When the Security Council takes action under Chapter VII, its decisions must be complied with and implemented by all UN member states. ${ }^{69}$

\section{SOUTHERN RHODESIA}

In December 1966, the Security Council used its sanctions powers under art. 41 of Chapter VII of the UN Charter for the very first time, applying sanctions against the illegal white minority regime, led by Ian Smith, that had taken control of Southern Rhodesia. In Resolution 232 (1966) the Council noted that it was acting in accordance with arts. 39 and $41,{ }^{70}$ determined that the "situation in Southern Rhodesia [constituted] a threat to international peace and security," same time, the Council reaffirmed "the inalienable rights of the people of Southern Rhodesia to freedom and independence." ${ }^{73}$ In subsequent decisions strengthening the scope of the Southern Rhodesia sanctions regime, the Council reaffirmed the importance of the objective of enabling the self-determination and independence of the Southern Rhodesian people. ${ }^{74}$ The sanctions remained in place until December 1979, shortly after the Smith regime relinquished control of Southern Rhodesia. ${ }^{75}$

\section{SOUTH AFRICA}

In November 1977, the Security Council imposed a mandatory arms embargo against South Africa. In Resolution 418 (1977) the Council called upon the South African government to end violence against its people and to take urgent steps to eliminate apartheid and racial discrimination. ${ }^{76}$ While the Council recognized that the military buildup by South Africa and its persistent acts of aggression against neighbouring states seriously disturbed the security of those states, ${ }^{77}$ the Council also condemned South Africa for its acts of repression and its continuance of the system of apartheid. ${ }^{78}$ In subsequent resolutions, the Council further characterized the South African government's policy of apartheid as

See UN Charter, ibid., art. 39 and, in general, Chapter VII (arts. 39-51).

Ibid., arts. 25, 48.

SC Res. 232, UN SCOR, 1966, UN Doc. S/RES/232, Preamble.

Ibid. at para. 1 .

Ibid. at para. 4.

Ibid.

See e.g. ibid.; SC Res. 253, UN SCOR, 1968, UN Doc. S/RES/253, Preamble, para. 2; SC Res. 277, UN SCOR, 1970, UN Doc. S/RES/277, Preamble, para. 4; SC Res. 288, UN SCOR, 1970, UN Doc. S/RES/288, Preamble, para. 2; SC Res. 318, UN SCOR, 1972, UN Doc. S/RES/318 at paras. 1-2; SC Res. 326, UN SCOR, 1973, UN Doc. S/RES/326, Preamble; SC Res. 328, UN SCOR, 1973, UN Doc. S/RES/328, Preamble, para. 3; SC Res. 386, UN SCOR, 1976, UN Doc. S/RES/386, Preamble; SC Res. 403, UN SCOR, 1977, UN Doc. S/RES/403, Preamble; SC Res. 424, UN SCOR, 1978, UN Doc. S/RES/424, Preamble; SC Res. 445, UN SCOR, 1979, UN Doc. S/RES/445, Preamble; SC Res. 448, UN SCOR, 1979, UN Doc. S/RES/448, Preamble; SC Res. 460, UN SCOR, 1979, UN Doc. S/RES/460 at para. 1; SC Res. 463, UN SCOR, 1980, UN Doc. S/RES/463 at para. 1.

SC Res. 460, ibid. at para. 2.

SC Res. 418, UN SCOR, 1977, UN Doc. S/RES/418, Preamble.

Ibid.

Ibid. 
"seriously [disturbing] international peace and security,"79 and reaffirmed the importance of the objectives of eliminating apartheid, ${ }^{80}$ establishing a democratic society, ${ }^{81}$ and ensuring the enjoyment of equal rights by all South Africans. ${ }^{82}$ The South Africa sanctions regime was eventually terminated in May 1994, when the Council welcomed the first all-race multi-party elections in South Africa and the inauguration of the Mandela administration, which it described as “a united, democratic, non-racial government." 83

\section{HAITI}

In June 1993, the Security Council imposed sanctions against Haiti in order to bring about the reinstatement of the democratically elected government of President Aristide, which had been ousted by a coup. In Resolution 841 (1993) the Council noted with concern the incidence of humanitarian crises, including mass displacements of population, becoming or aggravating threats to international peace and security, ${ }^{84}$ and stated that it deplored the fact that the legitimate Aristide government had not been reinstated. ${ }^{85}$ The Council then observed that the situation warranted "exceptional" measures by the Council in support of the efforts that had already been taken to resolve the situation, ${ }^{86}$ and it determined that, in those "unique and exceptional circumstances," the continuation of the situation in Haiti threatened international peace and security in the region. ${ }^{87}$ The Council then imposed targeted petroleum, arms, and financial sanctions against the de facto authorities in Haiti. ${ }^{88}$ The sanctions were subsequently strengthened and relaxed in response to alternately deteriorating then improving events in Haiti, before they were eventually terminated upon the return of President Aristide to Haiti on 15 October 1994.

\section{SIERRA LEONE}

In October 1997, the Security Council imposed sanctions against Sierra Leone in order to induce the military junta, which had come to power the previous May by means of a coup d'etat, to return control of the country to Sierra Leone's democratically elected government. In Resolution 1132 (1997) the Council deplored the fact that the military junta had not taken steps to allow the restoration of the democratically elected government and a return to constitutional order. ${ }^{89}$ The Council expressed its grave concern at the continued violence and loss of life in Sierra Leone following the coup, at the deteriorating humanitarian conditions in that country, and at the consequences for neighbouring countries. ${ }^{90}$ It then determined that

SC Res. 473, UN SCOR, 1980, UN Doc. S/RES/473 at para. 3.

SC Res. 418, supra note 76, Preamble; SC Res. 424, supra note 74, Preamble; SC Res. 473, ibid., Preamble, paras. 4-7; SC Res. 569, UN SCOR, 1985, UN Doc. S/RES/569 at para. 5; SC Res. 591, UN SCOR, 1986, UN Doc. S/RES/591, Preamble; SC Res. 765, UN SCOR, 1992, UN Doc. S/RES/765 at para. 7.

SC Res. 473, ibid., Preamble, paras. 4, 7; SC Res. 569, ibid., Preamble, para. 5; SC Res. 591, ibid.

SC Res. 473, ibid.; SC Res. 569, ibid., Preamble; SC Res. 591, ibid.

SC Res. 919, UN SCOR, 1994, UN Doc. S/RES/919, Preamble.

SC Res. 841, supra note 2, Preamble.

Ibid.

Ibid.

Ibid.

Ibid. at paras. 5-6, 8.

SC Res. 1132, supra note 2, Preamble.

Ibid. 
the situation in Sierra Leone constituted a threat to international peace and security in the region, ${ }^{91}$ and imposed targeted travel and petroleum sanctions, as well as an arms embargo. ${ }^{92}$ In June 1998, after the democratically elected government had been returned to power, the initial sanctions were terminated. But they were replaced by a new arms embargo, targeted travel sanctions, and diamond sanctions targeting the former military junta and the leaders of the major rebel group in Sierra Leone — the Revolutionary United Front (RUF). ${ }^{93}$

\section{IMPLICATIONS FOR THE DEMOCRATIC NORM THESIS}

The Security Council's actions in Southern Rhodesia, South Africa, Haiti, and Sierra Leone demonstrate a clear willingness to identify situations in which there is a denial of democracy as a threat to international peace and security and to employ coercive action, in the form of sanctions, to bring pressure to bear so that democracy is introduced or restored. A number of commentators have thus used these examples, and in particular the cases of Haiti and Sierra Leone, as an anchor for the claim that there is now a global norm of democratic governance. ${ }^{94}$

When assessing the parameters of the democratic norm thesis, it is important to note that in each of these situations the Council was at pains to depict the denial of democracy as one part of a background tapestry of circumstances, which, when taken as a whole, amounted to a threat to international peace and security. In the cases of Southern Rhodesia and South Africa, the regimes targeted were also engaging in aggressive activities that threatened other states in their region. In Haiti and Sierra Leone, the Council emphasized the deteriorating humanitarian situation as a key factor. In Southern Rhodesia, Haiti, and Sierra Leone, the Council was facing illegal regimes that had come to power by ousting governments that were either democratic or broadly accepted as legitimate by the international community. In South Africa, the Council was addressing the scourge of apartheid, an extreme policy of discrimination that attracted practically universal opposition and condemnation by UN member states. Finally, and tellingly, even in the Haiti instance, which is commonly pointed to as a clear example of the Council taking robust action in support of democracy, and where it might be possible to draw a close comparison with Zimbabwe in terms of the dire humanitarian situation, the Council went out of its way to stress that the circumstances it faced were "unique and exceptional" and the measures it was taking in response to those circumstances were similarly "exceptional."95

When these factors are taken into account, perhaps it is not so surprising that the Council was not able to adopt the Zimbabwe draft resolution. Indeed, if one were to sketch the contours of the democratic norm on the basis of these precedents, a fair characterization would be that, in situations where a democratic government has been unseated and the consequences of that unseating have a direct impact upon the peace and security of neighbour states and/or the region, the Security Council may take action under Chapter VII with the aim

Ibid.

Ibid. at paras. 5-6.

SC Res. 1171, UN SCOR, 1998, UN Doc. S/RES/1171 at paras. 1-3, 5.

See Tom J. Farer, “The Promotion of Democracy: International Law and Norms” in Newman \& Rich, supra note 29, 32 at 48-58.

SC Res. 841, supra note 2, Preamble. 
of restoring the democratically elected government so as to restore international peace and security. But even this tentative characterization should be taken with a grain of salt, for the Council is unlikely to take such action if it conflicts with the basic national interests of one of the P5.

\section{B. Other Security Council Decisions Promoting Democracy}

There is a tendency among some international legal commentators to focus solely or predominantly on Security Council decisions that are adopted under Chapter VII when exploring legally significant Security Council practice. While it is clear that Chapter VII decisions carry greater legal weight, the potential normative implications of decisions not explicitly adopted under Chapter VII should not be discounted or underestimated. When the International Court of Justice affirmed that the decisions of the Council are binding on all UN member states, it did not specify that it was referring only to Chapter VII decisions. ${ }^{96}$ Indeed, the plain language meaning of art. 25 of the UN Charter suggests that all decisions of the Council are binding on UN member states. ${ }^{97}$ Thus, those seeking to bolster the strength of the claim that there is a norm of democratic governance could look beyond the limited pool of democracy-related Chapter VII decisions to the Council's less high-profile, yet more workmanlike and numerous, decisions touching upon democracy and democratic governance.

A survey of the democracy-related resolutions adopted by the Security Council in 2007 provides an interesting insight into the Council's increasingly close day-to-day relationship with democracy. Twenty-two of the 55 resolutions adopted that year contain reference to democracy, democratic governance, democratic institutions, or elections. ${ }^{98}$ This amounts to a remarkable 40 percent of all resolutions adopted in that 12 -month period. These democracy-related references are not always significant from a normative perspective. At times the Council simply describes a government as democratically elected (Iraq ${ }^{99}$ ) or welcomes the fact that elections have taken place (Sierra Leone, ${ }^{100} \mathrm{Haiti}^{101}$ ). Yet even these apparently innocuous references indicate a general preference for domestic political systems that hold elections and promote democracy. The Council's democracy-related references can be grouped into four general categories: (i) those affirming the general importance of democracy and democratic institutions; (ii) those affirming the importance of elections for the promotion of peace; (iii) those tasking a UN operation or senior official with supporting democracy; and (iv) those appealing to other actors to support democracy.

Legal Consequences for States of the Continued Presence of South Africa in Namibia (South West Africa) Notwithstanding Security Council Resolution 276 (1970), Advisory Opinion, [1971] I.C.J. Rep. 16 at paras. $110-15$.

UN Charter, supra note 1, art. 25.

The table at the end of this article identifies these 22 resolutions and the provisions thereof relating to democracy.

SC Res. 1762, UN SCOR, 2007, UN Doc. S/RES/1762, Preamble; SC Res. 1770, UN SCOR, 2007, UN Doc. S/RES/1770, Preamble; SC Res. 1790, UN SCOR, 2007, UN Doc. S/RES/1790, Preamble. SC Res. 1793, UN SCOR, 2007, UN Doc. S/RES/1793, Preamble.

SC Res. 1743, UN SCOR, 2007, UN Doc. S/RES/1743, Preamble; SC Res. 1780, UN SCOR, 2007, UN Doc. S/RES/1780, Preamble. 


\section{THE IMPORTANCE OF DEMOCRACY AND DEMOCRATIC INSTITUTIONS}

The Security Council frequently underlines the importance of building democracy and democratic institutions. In Somalia, Haiti, and Iraq the Council welcomed efforts to create a democratic country. ${ }^{102}$ In Nepal it encouraged the restoration of democracy. ${ }^{103}$ In the case of Bosnia and Herzegovina, the Council recognized the importance of that country's transition to a democratic country. ${ }^{104}$ In the DRC it underscored the need for the government to consolidate democracy. ${ }^{105}$ In a general resolution addressing the situation in Chad, the Central African Republic, and the sub-region, the Council welcomed steps to reinforce the democratic process. ${ }^{106}$ In Afghanistan it expressed support for efforts to strengthen foundations of constitutional democracy. ${ }^{107}$ In Burundi the Council noted the need to consolidate democratically elected institutions. ${ }^{108}$

\section{The IMPORTANCE OF ELECTIONS FOR THE PROMOTION OF PEACE}

The Security Council regularly reaffirms the link between elections and peace. In the DRC it noted the importance of elections for establishing peace and stability. ${ }^{109}$ In Somalia it stressed the need for democratic elections to be included as part of a peace process. ${ }^{110} \mathrm{In}$ Sudan it emphasized the link between elections and the implementation of a peace process. ${ }^{111}$ In Côte d'Ivoire the Council noted the need for free and fair elections and subsequently took the significant step of making the holding of free and fair elections a precondition for reviewing sanctions. ${ }^{112}$ In the case of Timor-Leste, the Council has also noted the importance of elections for strengthening democracy. ${ }^{113}$

\section{TASKING UN PEACE OpERATIONS AND SENIOR OfFICIALS WITH SUPPORTING DEMOCRATIC PROCESSES AND INSTITUTIONS}

The most concrete way in which the Security Council demonstrates its commitment to democracy is through tasking UN peace operations (whether peacekeeping, peace-building, or special political missions) with taking practical steps to support democratic processes and institutions. In 2007, the Council mandated peace operations to provide general technical and/or material support for elections in no fewer than seven countries: Côte d'Ivoire, ${ }^{114}$ the

For Somalia, see SC Res. 1744, UN SCOR, 2007, UN Doc. S/RES/1744 at para. 2; for Haiti, see SC Res. 1780, ibid.; for Iraq, see SC Res. 1790, supra note 99, Preamble. SC Res. 1740, UN SCOR, 2007, UN Doc. S/RES/1740, Preamble. SC Res. 1785, UN SCOR, 2007, UN Doc. S/RES/1785, Preamble. SC Res. 1794, UN SCOR, 2007, UN Doc. S/RES/1794, Preamble. SC Res. 1778, UN SCOR, 2007, UN Doc. S/RES/1778, Preamble. SC Res. 1746, UN SCOR, 2007, UN Doc. S/RES/1746, Preamble. SC Res. 1791, UN SCOR, 2007, UN Doc. S/RES/1791, Preamble.

SC Res. 1756, UN SCOR, 2007, UN Doc. S/RES/1756, Preamble; SC Res. 1794, supra note 105, Preamble.

SC Res. 1772, UN SCOR, 2007, UN Doc. S/RES/1772, at para. 5.

SC Res. 1755, UN SCOR, 2007, UN Doc. S/RES/1755, Preamble.

SC Res. 1739, UN SCOR, 2007, UN Doc. S/RES/1739, Preamble; SC Res. 1782, UN SCOR, 2007, UN Doc. S/RES/1782 at para. 2(a).

SC Res. 1745, UN SCOR, 2007, UN Doc. S/RES/1745, Preamble.

For provisions tasking United Nations Operation in Côte d'Ivoire (UNOCI), see SC Res. 1739, supra note 112 at para. 2(j); SC Res. 1765, UN SCOR, 2007, UN Doc. S/RES/1765 at para. 1. 
DRC, ${ }^{115}$ Sudan, ${ }^{116}$ Haiti, ${ }^{117}$ Iraq, ${ }^{118}$ Nepal, ${ }^{119}$ and Sierra Leone. ${ }^{120}$ In Côte d'Ivoire and the DRC the Council also explicitly directed its peacekeeping operations to provide a stable environment for elections. ${ }^{121}$ The Council has also required its operations and officials to play an election monitoring role. In Côte d'Ivoire it tasked senior UN officials with certifying that elections are free and fair. ${ }^{122}$ In Nepal, in response to the request of local parties for the UN to assume such a role, the Council tasked the United Nations Mission in Nepal (UNMIN) with monitoring elections. ${ }^{123}$ In the DRC, the Security Council took the step of tasking a peacekeeping operation with supporting the strengthening of democratic institutions. ${ }^{124}$

\section{APpeAling to Other ACtORS to SUPPORT DemOCRATIC PROCESSES AND INSTITUTIONS}

The Security Council frequently appeals to governments to take steps to support democratic processes and institutions in their own country. In 2007, it encouraged the pursuit of democratic governance reforms (Burundi ${ }^{125}$ ) and the strengthening of democratic governance (Haiti ${ }^{126}$ ). It also appealed to governments to begin planning for the next elections (Afghanistan ${ }^{127}$ ), establish permanent and effective electoral institutions (Haiti ${ }^{128}$ ), provide the necessary support for elections (Sierra Leone ${ }^{129}$ and Sudan ${ }^{130}$ ), and hold elections $\left(\right.$ Haiti $\left.^{131}\right)$. In Timor-Leste, the Council also provided positive feedback on the efforts of the government to prepare for elections, welcoming the adoption of electoral laws. ${ }^{132}$

At times the Security Council has also appealed to the local or international community to support democracy. In Sudan the Council called on local parties to support elections. ${ }^{133}$ In Timor-Leste and Sierra Leone it appealed to local parties to ensure that elections were free

For provisions tasking United Nations Organization Mission in the DRC (MONUC), see SC Res. 1742, UN SCOR, 2007, UN Doc. S/RES/1742; SC Res. 1756, supra note 109, Preamble, para. 3(d); SC Res. 1794, supra note 105 at para. 12.

SC Res. 1784, UN SCOR, 2007, UN Doc. S/RES/1784 at para. 10 (tasking United Nations Mission in Sudan (UNMIS)).

SC Res. 1780, supra note 101 at para. 5 (tasking United Nations Stabilization Mission in Haiti (MINUSTAH)).

SC Res. 1770, supra note 99 at para. 2(a) (tasking United Nations Assistance Mission for Iraq (UNAMI)).

SC Res. 1740, supra note 103 at para. 1 (tasking UNMIN).

SC Res. 1793, supra note 100 at para. 3 (tasking United Nations Integrated Office in Sierra Leone (UNIOSIL)).

For Côte d'Ivoire, see SC Res. 1739, supra note 112 at para. 2(j) (tasking UNOCI); for the DRC, see SC Res. 1756, supra note 109 at para. 3(e) (tasking MONUC).

SC Res. 1765, supra note 114 at para. 6; SC Res. 1782, supra note 112, Preamble.

SC Res. 1740, supra note 103, Preamble, para. 1(e).

SC Res. 1756, supra note 109 at para. 3(a); SC Res. 1794, supra note 105 at para. 14.

SC Res. 1791, supra note 108 at para. 6.

SC Res. 1743, supra note 101, Preamble.

SC Res. 1746, supra note 107 at para. 16.

SC Res. 1780, supra note 101, Preamble.

SC Res. 1793, supra note 100 at para. 5.

SC Res. 1755, supra note 111, Preamble; SC Res. 1784, supra note 116, Preamble.

SC Res. 1780, supra note 101, Preamble.

SC Res. 1745, supra note 113, Preamble.

SC Res. 1755, supra note 111 at para. 3. 
and fair. ${ }^{134}$ In Timor-Leste the Council also called on local parties to adhere to democratic processes. ${ }^{135}$ The Council called on UN member states to provide technical and material support for elections in Sudan and Sierra Leone ${ }^{136}$ and it appealed to the international community to support efforts to pursue democracy in Iraq. ${ }^{137}$

\section{IMPLICATIONS FOR THE DEMOCRATIC NORM THESIS}

When one looks beyond the high-profile Chapter VII actions surveyed in Part A, it soon becomes apparent that the Security Council's formal relationship with democracy runs deeper than its relatively isolated coercive Chapter VII actions in Southern Rhodesia, South Africa, Haiti, and Sierra Leone. The Council's references to democracy might sometimes appear to be mere words or rhetoric, but it has also demonstrated a strong general commitment to the promotion of democratic processes (especially free and fair elections) and democratic institutions in the post-conflict environments where it has particular responsibility and influence. Indeed, the Council's increasingly common practice of promoting democracy in peacekeeping and peace-building theatres through the concrete activities of its peace operations provides a rich potential source of precedents and trends to construct the argument that a norm may be emerging requiring the international community to promote democratic processes (in particular free and fair elections) and strengthen democratic institutions in postconflict environments.

\section{RE-EVALUATING THE COUNCIL’S RELATIONSHIP WITH DEMOCRACY}

This article has sought to illustrate that the UN Security Council's relationship with democracy is closer than either the UN's extreme critics, on the one hand, or its supporters who overemphasize the Council's Chapter VII forays as the sole basis for its association with democracy, on the other, would have us believe. What does this analysis ultimately mean for the current status of the Security Council's relationship with the democratic norm thesis and the democratic deficit?

\section{A. RE-EVAluating The Democratic Norm Thesis}

The Security Council's failure to take Chapter VII action against Zimbabwe to restore democracy is a blow to those who would like to expand the democratic norm thesis beyond its current boundaries. If the Council had decided to intervene in Zimbabwe, it would have marked the first application of such extensive Chapter VII action against a sitting, originally democratically elected government, in order to restore democracy. ${ }^{138}$ If the draft resolution had been adopted instead of vetoed, democracy advocates could have pointed to the new

For Timor-Leste, see SC Res. 1745, supra note 113 at para. 6; for Sierra Leone, see SC Res. 1793, supra note 100 at para. 5 .

SC Res. 1745 , ibid. at para. 6.

For Sudan, see SC Res. 1784, supra note 116, Preamble; for Sierra Leone, see SC Res. 1793, supra note 100 at para. 5.

SC Res. 1790, supra note 99, Preamble.

The vetoed draft resolution would have applied a range of targeted sanctions, including an arms embargo, a travel ban, and an assets freeze against Mugabe and key members of his regime: see Zimbabwe Draft Resolution, supra note 1 at paras. 4-7. 
resolution as heralding an expansion of the democratic norm. But there was to be no discovery of new normative terrain this time.

Yet if democratic norm advocates gain cold comfort from the Security Council's response to Zimbabwe, they should be heartened by the Council's increasing practice of building democracy after conflict. Indeed, the Council's promotion of democracy in post-conflict environments represents a meaningful fleshing out of the less glamorous, more workmanlike parameters of the norm, which may ultimately have more practical and lasting effect than the rarely implemented Chapter VII dimensions of the norm. The Security Council's consistent support for building democracy after conflict raises the expectation that the international community, through the Council, will promote democracy, democratic processes, and democratic institutions, at least as part of its endeavours to support post-conflict peacebuilding.

\section{B. RE-EVALUATING THE COUNCIL'S RELATIONSHIP WITH THE DEMOCRATIC DEFICIT}

As noted in Part II, the Security Council's composition and decision-making process are largely undemocratic. There is no requirement that Security Council member states must be democracies. Moreover, the anointment of five states as permanent members effectively relegates the remaining members of the UN to second-class citizenship status. Indeed, the existence of the permanent member power of veto casts a long shadow over the Security Council's potential to act as a neutral, principled promoter of democracy. It ensures that the Council's forays into democracy promotion, no matter how well-intended or effective, will always be selective. Thus, the Council has promoted self-determination and democracy in places like South Africa, Haiti, Kosovo, and Timor-Leste, but not in Chechnya, Tibet, or Zimbabwe. For these reasons, the Council's omissions (or "silences" ${ }^{139}$ ) may be as instructive as its actions when it comes to assessing the quality of its commitment to democracy.

It is also possible to be critical not only of those instances when the Security Council has failed to act, but also of the manner in which it has approached its task even when it has decided to promote democracy. Some writers argue that the UN too often equates democracy with the mere holding of periodic elections. ${ }^{140}$ Others fear that the rush to democracy in the short-term might hinder the development of a truly sustainable democratic culture. ${ }^{141}$ Yet others underline that there is an irony in seeking to foster democracy in post-conflict environments by introducing transitional forms of governance that are undemocratic, such as transitional UN administrations ${ }^{142}$ or power-sharing arrangements between local protagonists who were responsible for sowing (and nurturing) the seeds of conflict. ${ }^{143}$ Others criticize the notion that democracy can be introduced by outsiders as if it were a form of

Hilary Charlesworth, "Feminist Methods in International Law" (1999) 93 A.J.I.L. 379 at 381 (noting that "the silences of international law may be as important as its positive rules and rhetorical structures"). Carothers, supra note 52 at 264.

See Maley, supra note 26.

See Simon Chesterman, "Building Democracy Through Benevolent Autocracy: Consultation and Accountability in UN Transitional Administrations” in Newman \& Rich, supra note 29, 86.

143 See Sid Noel, ed., From Power Sharing to Democracy: Post-conflict Institutions in Ethnically Divided Societies (Montreal: McGill-Queen’s University Press, 2005). 
technology, pointing out that external attempts to introduce democracy to foreign postconflict societies are suspiciously reminiscent of the self-serving colonial policies of previous eras, which sought to (re)engineer "uncivilized" societies so that they were receptive to Western values, ideas, interests, actors, and trade. ${ }^{144}$

Nevertheless, although the Security Council might operate in democratic deficit at a basic level, and although its interventions to promote democracy may exhibit flaws, the Council's concrete steps towards democracy promotion should not be overlooked when it comes to assessing the Council's relationship to the global democratic deficit. As Parts III through V illustrate, the Council has managed to negotiate an increasingly meaningful relationship with democracy. At a rhetorical level, it has underscored the need in different post-conflict situations to consolidate democracy, reinforce the democratic process, strengthen foundations of constitutional democracy, and consolidate democratically elected institutions. ${ }^{145}$ On a practical level it has explicitly tasked its peace operations with supporting and monitoring elections and with supporting the strengthening of democratic institutions. ${ }^{146}$ These constructive contributions to the promotion of democracy in post-conflict environments across the globe deserve to be acknowledged when assessing the Security Council's relationship with democracy.

The Security Council's relationship with democratic deficit is thus more complex than a cursory summary of its composition and procedures would suggest. It is misleading to claim that the Council unequivocally compounds the global democratic deficit. A more accurate, albeit less sexy, assessment is that although the Security Council is a less than ideal model when it comes to practising democracy within its own chambers, it has nonetheless managed to make a meaningful contribution to the promotion and strengthening of democracy in postconflict environments. Counterintuitively, the Council has the capacity to serve as a constructive force for the promotion of democracy, even while it remains a negative role model for the actual practice of democracy.

\section{LOOKING TO THE FUTURE}

So what does this suggest about the likely future relationship between the Security Council and democracy? On the one hand, the Council's approach to Zimbabwe and the attitude of Russia and China towards democracy more broadly indicate that we are unlikely to see the Council adventurously and frequently launching Chapter VII forays to protect, promote, or restore democracy. On the other hand, however, it is equally unlikely that we will see a reversal of policy on the promotion of democracy as part of post-conflict peacebuilding. In all likelihood the Council will continue to expand its growing practice of promoting democracy and democratic governance through the activities of UN peace operations. In the long run, perhaps this will have greater significance, both in practical and normative terms, for the future of the democratic norm than the occasional exercise (or veto thereof) of the Security Council's Chapter VII powers. 
TABLE OF PROVISIONS FROM

2007 SECURITY COUNCIL RESOLUTIONS TOUCHING UPON DEMOCRACY

\begin{tabular}{|c|c|c|}
\hline Resolution & Situation & Provision(s) \\
\hline 1739 (10 Jan 2007) & Côte d'Ivoire & Preamble, para. 2 \\
\hline 1740 (23 Jan 2007) & Nepal & Preamble, para. 1 \\
\hline 1743 (15 Feb 2007) & Haiti & Preamble \\
\hline 1742 (15 Feb 2007) & DRC & Preamble \\
\hline 1744 (20 Feb 2007) & Somalia & Para. 2 \\
\hline 1745 (22 Feb 2007) & Timor-Leste & Preamble, para. 6 \\
\hline 1746 (23 Mar 2007) & Afghanistan & Preamble, para. 16 \\
\hline 1755 (30 Apr 2007) & Sudan & Preamble, para. 3 \\
\hline 1756 (15 May 2007) & DRC & Preamble, para. 3 \\
\hline 1762 (29 June 2007) & Iraq & Preamble \\
\hline 1765 (16 July 2007) & Côte d'Ivoire & Paras. 1, 6, 7 \\
\hline 1770 (10 Aug 2007) & Iraq & Preamble, para. 2(a) \\
\hline 1772 (20 Aug 2007) & Somalia & Para. 5 \\
\hline 1778 (25 Sep 2007) & Chad and the subregion & Preamble \\
\hline 1784 (31 Oct 2007) & Sudan & Preamble, para. 10 \\
\hline 1780 (15 Oct 2007) & Haiti & Preamble, para. 5 \\
\hline 1782 (29 Oct 2007) & Côte d'Ivoire & Preamble, para. 2(a) \\
\hline 1785 (21 Nov 2007) & Bosnia and Herzegovina & Preamble \\
\hline 1791 (19 Dec 2007) & Burundi & Preamble, para. 6 \\
\hline 1790 (18 Dec 2007) & Iraq & Preamble \\
\hline 1794 (21 Dec 2007) & DRC & Preamble, paras. 12,14 \\
\hline 1793 (21 Dec 2007) & Sierra Leone & Preamble, paras. 3, 5 \\
\hline
\end{tabular}

